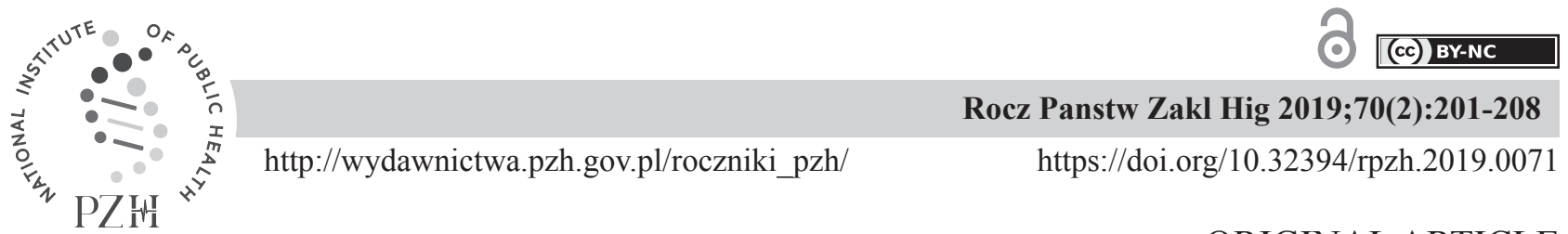

ORIGINAL ARTICLE

\title{
FAT MASS INDEX AND DIETARY BEHAVIOURS OF THE POLISH BORDER GUARD OFFICERS
}

\author{
Anna Anyżewska , Tomasz Lepionka ${ }^{1}$, Roman Łakomy ${ }^{1}$,Ewa Szarska ${ }^{2}$ Ewelina Maculewicz², \\ Andrzej Tomczak ${ }^{3}$, Izabela Bolczyk $k^{4}$, Jerzy Bertrandt ${ }^{1}$ \\ ${ }^{1}$ Laboratory of Food and Nutrition Hygiene, Military Institute of Hygiene and Epidemiology, Warsaw, Poland \\ ${ }^{2}$ Laboratory of Physiology, Military Institute of Hygiene and Epidemiology, Warsaw, Poland \\ ${ }^{3}$ War Studies University in Warsaw, Faculty of National Security, Department of Security Education, \\ Warsaw, Poland \\ ${ }^{4}$ The Polish Border Guard Headquarters, Warsaw, Poland
}

\begin{abstract}
Background. Due to specific requirements of service, Border Guard officers should be characterized by good health. Whereas there is lack of studies assessing nutritional status as well as dietary behaviours among Polish Border Guard officers.

Objective. The aim of the study was to assess the impact of dietary behaviours of the Polish Border Guard officers on the Fat Mass Index.

Material and methods. The study was carried out with participation of 250 Border Guard officers (187 men and 63 women), aged $37 \pm 6$; years of service: $12 \pm 6$. Nutritional status was determined with the electrical bioimpedance method using the TANITA MC-780 analyzer. According to the calculated Fat Mass Index value each person was qualified to one of the following groups: fat deficit, normal fat or excess fat. The Border Guard officers were asked to fill in the original questionnaire containing questions about nutritional behaviours in line with the recommendations of the Swiss Food Pyramid for Athletes in the basic version.

Results. The excessive amount of fat in every third officer of the Border Guard and numerous irregularities in eating behaviours were found. According to the food pyramid the smallest scale of rational dietary choices (especially regularity of meals, fruit and vegetable consumption) was characteristic of officers with excess fat. In addition, officers from the excess fat group obtained, on average, a lower sum of points for compliance of nutritional behaviours with the recommendations of the Swiss Food Pyramid than those from other groups ( $49 \%$ vs. 59\% and 56\%, p=0.002).

Conclusions. There is a need for nutritional education and further monitoring of both the nutritional status and dietary behaviours of Border Guard officers.
\end{abstract}

Key words: nutritional status, Fat Mass Index, dietary behaviours, food pyramid, border guards

\section{STRESZCZENIE}

Wprowadzenie. Z uwagi na specyfikę służby funkcjonariusze Straży Granicznej powinni charakteryzować się dobrym stanem zdrowia. Tymczasem brakuje badań na temat stanu odżywienia, jak również zachowań żywieniowych funkcjonariuszy Straży Granicznej w Polsce.

Cel. Celem badań była ocena wpływu zachowań żywieniowych na Wskaźnik Tkanki Tłuszczowej funkcjonariuszy Straży Granicznej pełniących służbę w Polsce.

Materiał i metody. Badania przeprowadzono w 2018 roku z udziałem 250 funkcjonariuszy Straży Granicznej (187 mężczyzn i 63 kobiet) w wieku $37 \pm 6$ lat, pełniących służbę od $12 \pm 6$ lat. Stan odżywienia oceniono metodą elektrycznej bioimpedancji z użyciem analizatora TANITA MC-780. Na podstawie obliczonej wartości Wskaźnika Tkanki Tłuszczowej każdą z osób zakwalifikowano do jednej z następujących grup: zbyt niska ilość tkanki tłuszczowej, prawidłowa ilość tkanka tłuszczowa lub nadmierna ilość tkanki tłuszczowej. Funkcjonariuszy poproszono o wypełnienie autorskiego kwestionariusza ankiety, zawierającego pytania na temat zachowań żywieniowych zgodnych z rekomendacjami szwajcarskiej piramidy żywienia dla sportowców w wersji podstawowej.

Wyniki. Stwierdzono nadmierną ilość tkanki tłuszczowej u co trzeciego funkcjonariusza Straży Granicznej oraz liczne nieprawidłowości w zachowaniach żywieniowych tych osób. W odniesieniu do piramidy żywienia najmniejszą skalą racjonalnych wyborów żywieniowych (w szczególności dotyczącą regularności posiłków oraz spożycia owoców i warzyw) charakteryzowali się funkcjonariusze z nadmierną tkanką tłuszczową. Ponadto, funkcjonariusze z nadmierną ilością tkanki

Corresponding author: Anna Anyżewska, Military Institute of Hygiene and Epidemiology, Laboratory of Food and Nutrition Hygiene, Kozielska Street 4, 01-163 Warsaw, Poland, Tel +48-261-853-145, e-mail: anna.anyzewska@wihe.pl

(C) Copyright by the National Institute of Public Health - National Institute of Hygiene 
tłuszczowej uzyskali średnio niższą sumę punktów za zgodność zachowań żywieniowych z zaleceniami szwajcarskiej piramidy żywienia niż badani z pozostałych grup ( $49 \%$ vs $59 \%$ i $56 \%$; $\mathrm{p}=0.002)$.

Wnioski. Istnieje potrzeba edukacji żywieniowej oraz dalszego monitorowania zarówno stanu odżywienia jak i zachowań żywieniowych funkcjonariuszy Straży Granicznej.

Slowa kluczowe: stan odżywienia, wskaźnik tkanki tluszczowej, zachowania żywieniowe, piramida żywieniowa, straż graniczna

\section{INTRODUCTION}

Proper nutrition along with appropriate level of physical activity are key factors for keeping good health. Irregularities in the diet are correlated with occurrence of diet-related metabolic diseases such as diabetes, dislipidemia, obesity and hypertension and other cardiovascular diseases [3, 16, 21]. Disorders in the nutrition manner have also been associated with an increased risk of osteoporosis and cancer [24, 36]. Diet-related metabolic diseases, although they do not manifest in a rapid course, can result in serious health consequences such as heart attack and stroke, which can not only lead to elimination of a patient from professional and social life, but often make a direct threat to life, as the main cause of death in Poland [35].

Keeping a good health condition is crucial, especially for officers of uniformed services, including officers of the Border Guard (BG). Numerous tasks of this formation created in 1991, defined by the Legislator in art. 1. of the Act of 12 October 1990 on the Border Guard [34] include varied activities for border protection and border traffic control in the Republic of Poland. Due to the shape of state borders, fulfillment of the above tasks is related to realization of activities in diverse geographical conditions, from sea activities to high-mountain ones, therefore BG officers should be characterized by good health and high level of physical fitness. Irregularities in nutrition of officers manifested in occurrence of overweight, obesity or underweight may result in difficulties in fulfillment of service tasks, and due to further health consequences, may be an indirect cause of early elimination from the service for health reasons [28].

The current issue of irregularities in the nutritional status of Border Guard officers and their possible health consequences may be provided by epidemiological data obtained from occupational medicine examinations. In the group of BG officers examined in 2012-2018 $(\mathrm{n}=54303), 23 \%$ were diagnosed with specific diseases, among which cardiovascular diseases, obesity and type 2 diabetes accounted for $20 \%, 28 \%$ and $1.7 \%$ of cases respectively (own data unpublished). These data indicate occurrence of health disorders associated most probably with abnormal nutritional behaviours of the examined officers.

Due to the limited number of scientific publications addressing the nutritional status of uniformed services officers, this publication attempts to assess the impact of dietary behaviours of Border Guard officers on the protein and energy nutritional status expressed as the Fat Mass Index (FMI). Association between value of the FMI index and degree of BG officers compliance with the principles of proper nutrition in relation to recommendations contained in the nutrition pyramid developed by the Swiss Society for Nutrition for athletes was also tested. [4]. Due to the nature of service, including need to maintain high level of psychophysical fitness by the BG officers, the work refers to the Swiss Pyramid of nutrition for sportsmen in the basic version.

\section{MATERIAL AND METHODS}

The research was conducted from June to October 2018 with participation of 187 male and 63 female officers of the BG, aged from 21 to 54 . To carry out the tests approval of the Bioethics Committee at the Military Institute of Hygiene and Epidemiology in Warsaw was obtained (1/XXI/2016). All guards officers, after getting acquainted with the information about conducted research, voluntarily gave their written consent to participate in the study.

Nutritional status was determined using the electrical bioimpedance method with the TANITA MC780 analyzer. In order to determine the correctness of fat content of the subjects, for each person the Fat Mass Index (FMI): FMI $\left[\mathrm{kg} / \mathrm{m}^{2}\right]=$ fat mass $/$ height $^{2}$ was calculated. Then, the subjects were qualified to one of the following groups: fat deficit: male $<3$, female $<5$; normal fat: male 3-6, female 5-9; excess fat: male $>6$, female $>9$, according to the Kelly et al. classification [17].

The subjects were asked to fill in the original questionnaire containing questions about nutritional behaviours in line with the recommendations of the Swiss Food Pyramid for Athletes in the basic version, i.e. intended for use in the general population, without taking into account additional portions of selected food products groups in connection with sport training taken above 5 hours per week [4]. During preparation of the survey, this questionnaire was modeled on research conducted in this field by other authors among various groups of athletes [8-12]. The Swiss Food Pyramid was validated using 168 menus prepared in accordance with established recommendations [23]. 
Table 1. Adherence of Border Guard officers to the recommendations of the Swiss Food Pyramid for Athletes (the basic pyramid) according to the Fat Mass Index classification

\begin{tabular}{|c|c|c|c|c|}
\hline \multirow[b]{2}{*}{ Recommendation } & \multicolumn{3}{|c|}{ FMI $[\%]$} & \multirow[b]{2}{*}{$\mathrm{p}$} \\
\hline & $\begin{array}{l}\text { Fat deficit } \\
\quad(n=31)\end{array}$ & $\begin{array}{c}\text { Normal } \\
\text { fat } \\
(n=139)\end{array}$ & $\begin{array}{c}\text { Excess } \\
\text { fat } \\
(\mathrm{n}=80)\end{array}$ & \\
\hline 1-2 liters of liquids a day & 74 & 81 & 91 & $0.045 * *$ \\
\hline Hydration with mineral water and other non-sweetened beverages & 87 & 91 & 88 & 0.591 \\
\hline Hydration during exercise & 90 & 92 & 90 & 0.857 \\
\hline Variable diet & 55 & 50 & 36 & 0.134 \\
\hline Eating regularly (every 3-5 hours) & 57 & 42 & 26 & $0.012 * *$ \\
\hline At least 3 meals per day & 87 & 89 & 79 & 0.164 \\
\hline At least 5 servings of fruits and vegetables per day & 23 & 16 & 10 & 0.226 \\
\hline At least 2 servings of fruits per day & 70 & 56 & 37 & $0.002 * *$ \\
\hline At least 3 servings of vegetables per day & 26 & 18 & 9 & $0.056^{*}$ \\
\hline Raw vegetables at least once a day & 52 & 52 & 43 & 0.430 \\
\hline At least 3 servings of whole grain or legumes & 39 & 40 & 33 & 0.571 \\
\hline Whole grain cereals at least twice a day & 48 & 37 & 33 & 0.185 \\
\hline 1 serving of meat, fish, eggs, cheese or tofu per day & 77 & 79 & 70 & 0.307 \\
\hline Fish 2 times per week & 33 & 24 & 18 & 0.104 \\
\hline 3 servings of dairy products per day & 29 & 42 & 41 & 0.383 \\
\hline 3 servings of plant-based oils per day & 48 & 53 & 35 & $0.042 * *$ \\
\hline 1 serving of nuts per day & 32 & 14 & 10 & $0.013 * *$ \\
\hline Reduced intake of animal fats & 45 & 51 & 44 & 0.510 \\
\hline Reduced intake of sweets & 61 & 47 & 50 & 0.380 \\
\hline Reduced intake of salted snacks & 74 & 62 & 61 & 0.397 \\
\hline Reduced intake of fast-food products & 74 & 76 & 60 & $0.047 * *$ \\
\hline Reduced intake of carbonated beverages & 81 & 84 & 78 & 0.590 \\
\hline Reduced intake of energy drinks & 90 & 92 & 85 & 0.382 \\
\hline Average & 59 & 56 & 49 & $0.002^{\mathrm{KW}}$ \\
\hline
\end{tabular}

Fat deficit: male $<3$, female $<5$; normal fat: male 3-6, female 5-9; excess fat: male $>6$, female $>9$

* statistical tendency: $C h i^{2}$ test, $0.05 \leq \mathrm{p} \leq 0.10$

** statistical significance: $C h i^{2}$ test, $\mathrm{p}<0.05$

${ }^{\mathrm{KW}}$ statistical significance: Kruskal-Wallis test, $\mathrm{p}<0.05$

The subjects were asked to answer "yes" or "no" to each of 23 selected statements describing dietary behaviours according to the pyramid of nutrition, such as: hydration methods and preferences, frequency and regularity of meals, frequency consumption of recommended food products, avoidance of foods that are non-recommended in rational diet. The next part of the questionnaire contained questions about personal information (sex, age, years of service and education).

The analysis of the results was carried out using the STATISTICA ver. 13 program. Compatibility of distribution of variables with normal distribution was assessed using the Shapiro-Wilk test, assuming the significance level of $\alpha=0.05$. Correctness of nutritional behaviours depending on correctness of the Fat Mass Index was assessed using the Kruskal-Wallis test. The Mann-Whitney $\mathrm{U}$ test was used to compare Fat Mass Index values depending on declaration of specific recommendations fulfillment. For specified statistically significant statements, a two-way analysis of variance was additionally performed in order to check whether there is an interaction of influence of two factors, i.e. compliance with the recommendation and gender of the subjects. The Spearman's correlation test was used to assess relationship between the Fat Mass Index values among the subjects and the sum of points obtained for statements consistent with the recommendations of the food pyramid. In the carried out analyzes, the significance level of $\alpha=0.05$ and the level of statistical tendency for $p$ in the range from 0.05 to 0.10 were assumed.

\section{RESULTS}

The average age of examined Border Guard officers amounted to $37 \pm 6$ years, and the average period of serving was $12 \pm 6$ years. Over $3 / 4$ of subjects (79\%) were higher educated, while others - secondary 
educated. The FMI values calculated for officers ranged from 1.3 to $13.0 \mathrm{~kg} / \mathrm{m}^{2}$ and for the fat deficit, normal and excess fat groups $12 \%, 56 \%$ and $32 \%$ of subjects were classified respectively.

The percentage of responses given by Border Guard officers, which were consistent with the principles of proper nutrition in relation to the Swiss Food Pyramid, varied widely and ranged from 15 to $91 \%$ (Figure 1). The subjects met the recommendations to the smallest extent for consuming 5 portions of fruit and vegetables every day (15\%), as well as consuming one portion of nuts per day (15\%), three portions of vegetables every day $(16 \%)$ and fish twice a week (23\%). The highest percentage of subjects implemented recommendations regarding hydration during training $(91 \%)$, preference for water and unsweetened drinks for general hydration $(90 \%)$ and reducing limiting consumption of energy drinks $(90 \%)$. The majority of subjects consumed at least 3 meals a day $(86 \%)$, but only $39 \%$ of officers consumed these meals regularly, maintaining a 3-5 hour interval. Only every second subject used a varied diet.

There were statistically significant differences for answers given to 6 out of 23 statements regarding nutritional behaviours and a summary of the average number of correct behaviours between groups distinguished due to the FMI classification (Table 1). The highest differences were noted in answers given to the question about consuming at least two portions of fruit per day $(p=0.002)$, then eating meals regularly $(p=0.012)$ and eating a portion of nuts daily $(\mathrm{p}=0.013)$. The affirmative answers to these questions were given by $70 \%, 57 \%$ and $32 \%$ of officers from the fat deficit group, $56 \%, 42 \%$ and $14 \%$ from the normal fat group and $37 \%, 26 \%$ and $10 \%$ from the excess fat group respectively. It was also shown that officers with excessive fat were less likely to eat 3 servings of plant-based oils per day $(\mathrm{p}=0.042)$ and to a lesser extent limited consumption of fast-food products $(\mathrm{p}=0.047)$, and more often than others drank 1-2 liters of liquids a day ( $\mathrm{p}=0.045)$. In addition, officers from the excess fat group obtained, on average, a lower sum of points for compliance of nutritional behaviours with the recommendations of the Swiss Food Pyramid than those from other groups ( $49 \%$ vs. $59 \%$ and $56 \%$, $\mathrm{p}=0.002$ ).

A negative correlation was found between the FMI and the sum of points obtained for correctness of nutritional behaviours $(p=0.015, R=-0.15)$. A detailed analysis, after separating new subgroups due to the sex of the subjects, confirmed statistical significance only among men (men: $\mathrm{p}<0.001, \mathrm{R}=-0.24$, women: $\mathrm{p}=0.479, \mathrm{R}=-0.09$ ).

Table 2. Fat Mass Index according to the adherence of Border Guard officers to the recommendations of the Swiss Food Pyramid for Athletes (the basic pyramid)

\begin{tabular}{|c|c|c|c|c|c|c|c|c|c|c|c|}
\hline \multirow{2}{*}{ Recommendation } & \multicolumn{5}{|c|}{ Not complying } & \multicolumn{5}{|c|}{ Complying } & \multirow{2}{*}{$\mathrm{p}$} \\
\hline & $\mathrm{X}$ & SD & $\mathrm{Me}$ & Min & Max & $\mathrm{X}$ & SD & $\mathrm{Me}$ & Min & Max & \\
\hline 1-2 liters of liquids a day & 5.42 & 1.71 & 5.13 & 2.37 & 9.06 & 5.81 & 2.09 & 5.63 & 1.30 & 12.9 & 0.342 \\
\hline Hydration with mineral water and other non-sweetened beverages & 5.85 & 2.07 & 5.44 & 2.59 & 11.4 & 5.73 & 2.04 & 5.58 & 1.30 & 12.9 & 0.778 \\
\hline Hydration during exercise & 6.23 & 2.51 & 5.82 & 2.58 & 12.9 & 5.70 & 1.98 & 5.56 & 1.30 & 11.9 & 0.473 \\
\hline Variable diet & 6.04 & 2.16 & 5.82 & 2.30 & 12.9 & 5.40 & 1.84 & 5.33 & 1.30 & 11.6 & $0.038 * *$ \\
\hline Eating regularly (every 3-5 hours) & 5.99 & 2.12 & 5.83 & 2.25 & 12.9 & 5.37 & 1.86 & 5.14 & 1.30 & 11.6 & $0.023 * *$ \\
\hline At least 3 meals per day & 6.21 & 2.13 & 6.15 & 2.25 & 11.4 & 5.67 & 2.02 & 5.48 & 1.30 & 12.9 & 0.114 \\
\hline At least 5 servings of fruits and vegetables per day & 5.79 & 2.04 & 5.63 & 1.30 & 11.9 & 5.27 & 1.67 & 5.38 & 1.53 & 8.63 & 0.272 \\
\hline At least 2 servings of fruits per day & 6.05 & 2.06 & 5.92 & 1.30 & 12.9 & 5.49 & 2.00 & 5.37 & 1.53 & 11.9 & $0.037 * *$ \\
\hline At least 3 servings of vegetables per day & 5.82 & 2.05 & 5.64 & 1.30 & 12.9 & 5.33 & 1.93 & 4.96 & 1.53 & 10.5 & 0.188 \\
\hline Raw vegetables at least once a day & 5.74 & 1.98 & 5.70 & 1.30 & 11.4 & 5.74 & 2.15 & 5.38 & 1.53 & 12.9 & 0.711 \\
\hline At least 3 servings of whole grain or legumes & 5.81 & 1.99 & 5.74 & 1.30 & 11.9 & 5.63 & 2.12 & 5.36 & 1.53 & 12.9 & 0.345 \\
\hline Wholegrain cereals at least twice a day & 5.87 & 2.03 & 5.66 & 1.30 & 11.9 & 5.58 & 2.08 & 5.38 & 1.53 & 12.9 & 0.359 \\
\hline 1 serving of meat, fish, eggs, cheese or tofu per day & 5.82 & 2.06 & 5.89 & 2.25 & 11.2 & 5.72 & 2.03 & 5.51 & 1.30 & 12.9 & 0.553 \\
\hline Fish 2 times per week & 6.00 & 2.04 & 5.78 & 2.25 & 12.9 & 4.99 & 1.86 & 4.77 & 1.30 & 9.38 & $0.001^{* *}$ \\
\hline 3 servings of dairy products per day & 5.72 & 2.18 & 5.42 & 1.30 & 12.9 & 5.76 & 1.83 & 5.65 & 1.53 & 11.9 & 0.499 \\
\hline 3 servings of plant-based oils per day & 5.87 & 2.02 & 5.64 & 1.30 & 11.2 & 5.60 & 2.05 & 5.54 & 1.53 & 12.9 & 0.258 \\
\hline 1 serving of nuts per day & 5.81 & 1.97 & 5.66 & 1.30 & 12.9 & 5.37 & 2.36 & 4.68 & 1.53 & 11.9 & $0.053^{*}$ \\
\hline Reduced intake of animal fats & 5.75 & 2.03 & 5.60 & 1.30 & 12.9 & 5.72 & 2.04 & 5.57 & 1.53 & 11.9 & 0.827 \\
\hline Reduced intake of sweets & 5.83 & 1.95 & 5.57 & 2.25 & 11.9 & 5.66 & 2.12 & 5.58 & 1.30 & 12.9 & 0.464 \\
\hline Reduced intake of salted snacks & 5.89 & 1.94 & 5.71 & 2.37 & 11.9 & 5.66 & 2.09 & 5.52 & 1.30 & 12.9 & 0.293 \\
\hline Reduced intake of fast-food products & 5.94 & 1.91 & 5.95 & 2.30 & 11.4 & 5.66 & 2.09 & 5.35 & 1.30 & 12.9 & 0.131 \\
\hline Reduced intake of carbonated beverages & 5.96 & 2.25 & 5.63 & 2.44 & 11.4 & 5.70 & 1.99 & 5.57 & 1.30 & 12.9 & 0.624 \\
\hline Reduced intake of energy drinks & 5.81 & 2.05 & 5.98 & 2.59 & 10.2 & 5.74 & 2.04 & 5.55 & 1.30 & 12.9 & 0.807 \\
\hline
\end{tabular}

$\mathrm{X}$ - arithmetic average, SD - standard deviation, Me - median, Min - minimum, Max - maximum

* statistical tendency: Mann-Whitney $U$ test, $0.05 \leq \mathrm{p} \leq 0.10$

** statistical significance: Mann-Whitney $U$ test, $\mathrm{p}<0.05$ 


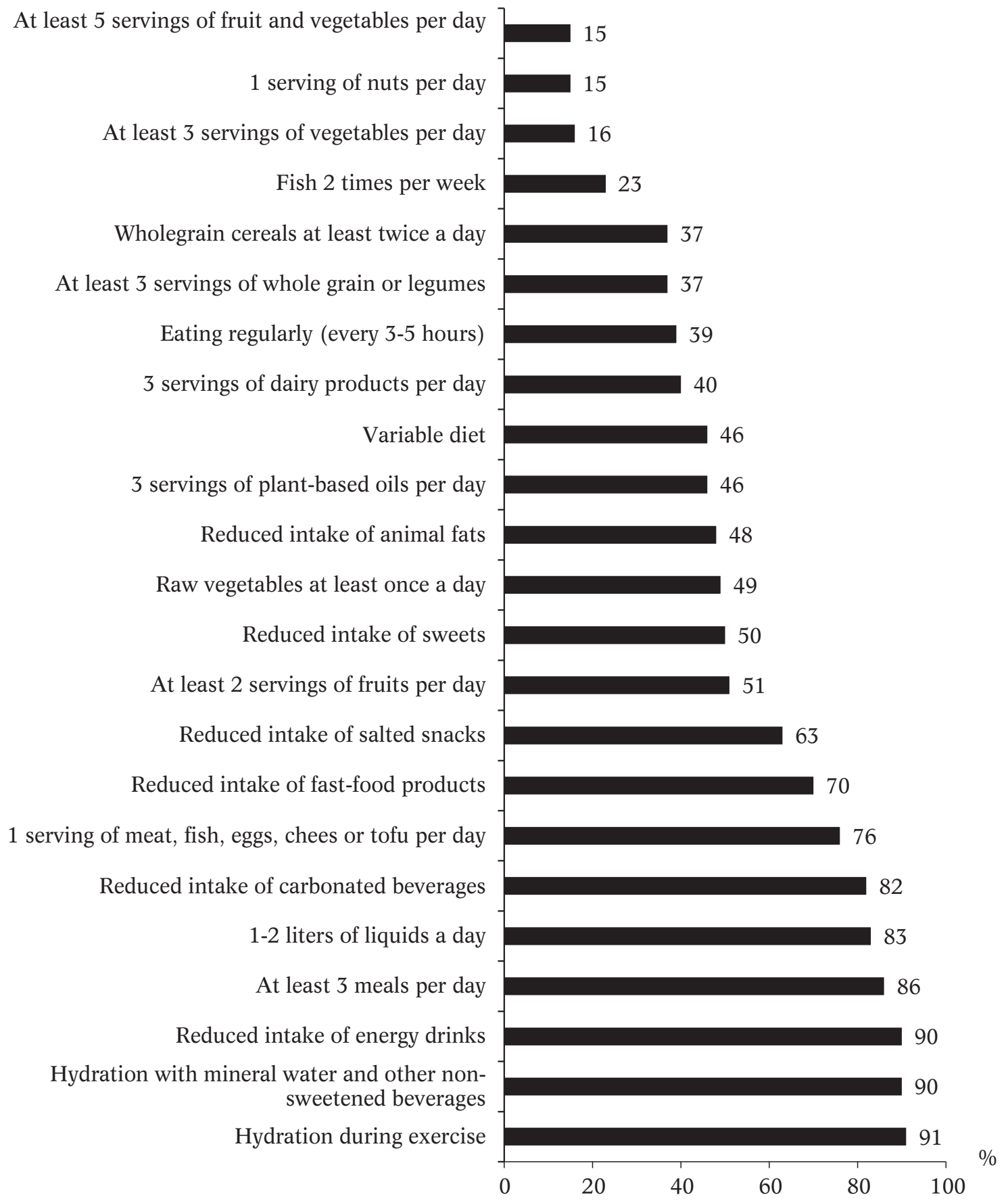

Figure. 1. Adherence of Border Guard officers to the recommendations of the Swiss Food Pyramid for Athletes (the basic pyramid)

Four out of 23 statements describing nutritional behaviours consistent with the food pyramid differentiated the FMI value depending on the subjects' compliance with these recommendations (Table 2). BG officers using a varied diet $(\mathrm{p}=0.038)$, eating meals regularly $(\mathrm{p}=0.023)$, consuming fruits at least twice a day $(\mathrm{p}=0.037)$ and consuming fish twice a week ( $\mathrm{p}=0.001)$, as well as consuming nuts daily $(\mathrm{p}=0.053)$ were characterized by a smaller FMI value. A two-factor analysis of variance showed an interaction between the examined factors (sex and the recommendation fulfillment) only in one recommendation, i.e. two portions of fruit a day, which depending on the sex of the subjects varied the Fat Mass Index of these people $(p=0.005)$. Using the Post hoc Tukey test statistically significant differences between the FMI of men and women fulfilling this recommendation (FMI of women eating fruit twice a day $=6.61 \mathrm{~kg} / \mathrm{m}^{2}$ and FMI for men eating fruit twice a day $=4.99 \mathrm{~kg} / \mathrm{m}^{2} ; \mathrm{p}<0.001$ ) were shown, as well as in the group of men due to the fulfillment of the recommendation (FMI for men eating fruit twice a day $=4.99 \mathrm{~kg} / \mathrm{m}^{2}$ and FMI for men who do not comply with this recommendation $=6.07 \mathrm{~kg} / \mathrm{m}^{2}, \mathrm{p}<0.001$ ). 


\section{DISCUSSION}

The carried out research revealed excessive amount of fat in every third officer of the Border Guard and numerous irregularities in the nutritional behaviours of these people. In recent years, as in general population, excessive body mass is more and more often observed among officers of other groups of uniformed services, e.g. soldiers $[1,19,20,27,29]$, police officers $[25,31]$ and firefighters $[2,18]$.

A state of human health, in particular the nutritional status, depends to a large extent on a nutrition manner. That is why experts have been creating and publishing dietary recommendations in various forms - not only as nutrition standards but also as food pyramids that are present in various countries around the world. Their main task is to provide nutritional recommendations in an accessible way, as well as encouragement to physical activity [5]. Research carried out by other authors regarding evaluation of sportsperson nutrition in relation to the Swiss Food Pyramid showed differences in fulfillment of individual recommendations due to the sports level, indicating more rational dietary choices in competitive athletes than amateurs practicing volleyball [9] and long-distance runners [12], or tendency to fuller implementation of the recommendations of the Swiss Pyramid by women than by men $[8,11]$. However, none of these studies considered the nutritional status of these people.

Due to the nature of the service of Border Guard officers and the requirements for general health, in particular high physical fitness, it seems justified to use the Swiss Pyramid also for this population group. General level of fulfillment of recommendations contained in the Swiss Food Pyramid by the Border Guard officers (49-59\%) should be considered insufficient. The subjects implemented the recommendations regarding hydration of the body, eating at least 3 meals a day and eating one portion of meat, fish, eggs, cheese or tofu daily. However, more than half of the subjects declared not remaining on a variable diet. In addition, officers, regardless of the level of adipose tissue, fulfilled recommendations regarding consumption of 5 portions of fruit and vegetables (10-23\% of subjects) to the smallest extent. Similar nutritional errors, i.e. insufficient consumption of cereal products, fish, fruit and vegetables and dairy products, as well as smaller than recommended number of meals were also observed in the total population [6] and among athletes [13, 30, 32, 33]. Research conducted with participation of another group of uniformed services also shown an insufficient frequency of eating fruit and vegetables and milk and its products among soldiers [14]. In addition, it has been shown that along with duration of the service, frequency of fruit and dairy products consumption by soldiers is reduced, and thus the Healthy Eating Index-2010 decreases [7]. According to the principles of proper nutrition, it is recommended to eat 4-5 properly balanced meals during a day in order to ensure maintenance of a constant level of glucose in the blood and regular supply of essential nutrients [15]. Insufficient consumption of fruit and vegetables can lead to unbalanced supply of some antioxidant vitamins, which are especially important in the increased oxidative stress condition associated with, for example, intensive exercise [26]. Moreover, low frequency of cereal products consumption, in particular from full milling, may promote deficiency of B vitamins and influence reduction of exercise capacity, as well as increase risk of fiber deficiency. And inadequate consumption of dairy products can lead to calcium deficiency. Calcium is the basic building material of bones and teeth and is involved in regulation of neuromuscular excitability and acid-base balance of the system [15]. Moreover, a properly balanced daily food intake secures the body, among others against a decrease in concentration, which is especially important among people whose work requires maintaining high psychophysical fitness and protects against fatigue [22].

The smallest scale of rational dietary choices was characteristic of officers with excessive adipose tissue (excess fat: male $>6 \mathrm{~kg} / \mathrm{m}^{2}$, female $>9 \mathrm{~kg} / \mathrm{m}^{2}$ ), which may explain their nutritional status. In the examined group, a negative correlation between the sum of points obtained for correctness of nutritional behaviours (according to the food pyramid) and the FMI value was found. In addition, nutritional behaviours differentiating level of the adipose tissue index among the subjects, such as regularity of eating meals, the varied diet, consumption of two portions of fruit a day, consumption of fish twice a week and daily consumption of nuts were distinguished. Officers complying with these recommendations were characterized by lower FMI values compared to the subjects who declared failure to fulfillment of these recommendations. More rational food choices favored maintaining the right amount of adipose tissue in Border Guard officers. Thus, the existence of relationship between the nutritional status and the nutrition manner of BG officers was confirmed.

\section{CONCLUSIONS}

1. The carried out research has shown excessive amount of fat in every third officer of the Border Guard and numerous irregularities in eating behaviours, including lack of variety and regularity of eating, as well as insufficient frequency of eating fruit and vegetables, whole grain products, dairy products, fish and nuts.

2. Dependencies between the Fat Mass Index and correctness of nutrition manner in relation to recommendations included in the Swiss Food Pyramid were revealed. 
3. There is a need for nutritional education and further monitoring of both the nutritional status and dietary behaviours of Border Guard officers.

\section{Conflict of interest}

The authors declare no conflict of interest.

\section{REFERENCES}

1. Bertrandt J., Kłos A., Łakomy R., Maculewicz E.: Stan odżywienia i uwapnienia kości żołnierzy 16 Batalionu Powietrzno-Desantowego [Nutritional status and bone calcification of soldiers serving in 16th Airborne Battalion]. Probl. Hig. Epidemiol. 2018;99(1):43-46 (in Polish).

2. Bertrandt J., Kłos A., Szymańska W., Walecka I.: Wpływ specyfiki studiów na stan odżywienia białkowo-energetycznego i mineralnego studentów I roku Szkoły Głównej Służby Pożarniczej (SGSP) [An effect of the study specificity on protein-energy and mineral nutritional status of the Main School of Fire Service (MSFS) students]. Pol. Przegl. Med. Lotn. 2011;17(1):33-42 (in Polish).

3. Brzuskiewicz P., Grzymistawski M., Swora-Cwynar E., Bogdański P.: Ocena stanu odżywienia i sposobu żywienia w zespole metabolicznym [Assessment of nutritional status and feeding methods in metabolic syndrome]. Forum Zaburzeń Metabolicznych. 2014;5(3):100-107 (in Polish).

4. Burke L.M.: A food pyramid for Swiss athletes. Int. J. Sport Nutr. Exerc. Metab. 2008;18(4):430-437.

5. Catyniuk B., Grochowska-Niedworok E., Bialek A., Czech N., Kukielczak A.: Piramida żywienia - wczoraj i dziś [Food guide pyramid - its past and present]. Probl. Hig. Epidemiol. 2011;92(1):20-24 (in Polish).

6. Centrum Badania Opinii Społecznej: Zachowania żywieniowe Polaków. Komunikat z badań. [Centre for Public Opinion Research. Dietary habits of Poles. Research summary], Warszawa 2014.

7. Farina E.K., Taylor J.C., Means G.E., Murphy N.E., Pasiakos S.M., Lieberman H.R., McClung J.P.: Effects of deployment on diet quality and nutritional status markers of elite U.S. Army special operations forces soldiers. Nutr J. 2017;3:16(1):41 doi: 10.1186/s12937017-0262-5.

8. Fraczek B., Brzozowska E., Morawska M.: Ocena zachowań żywieniowych zawodników trenujących gry zespołowe w świetle rekomendacji piramidy żywieniowej dla sportowców [Assessment of nutritional habits in athletes practicing team sports in view of the Swiss food pyramid recommendations]. Probl Hig Epidemiol 2013;94(2):280-285 (in Polish).

9. Gacek M., Popek A.: Analiza zachowań żywieniowych mężczyzn wyczynowo i amatorsko trenujących piłkę siatkową. [Analysis of nutritional behaviours of males - competitive and recreational volleyball players]. Sport i Turystyka. Środkowoeuropejskie Czasopismo Naukowe 2018;1(2):93-102 (in Polish) doi: 10.16926/ sit.2018.01.16.
10. Gacek M.: Association between self-efficacy and dietary behaviours of American football players in the Polish clubs in the light of dietary recommendations for athletes. Rocz Panstw Zakl Hig 2015;66(4):361-366.

11. Gacek M.: Dietary behaviours of winter sport athletes. Med. Sport. 2016;4(4);32:251-260 doi: 10.5604/1232406X.1229086.

12. Gacek M.: Zachowania żywieniowe grupy młodych mężczyzn trenujących biegi długodystansowe. [Eating habits of young male long-distance runners]. Med. Og. Nauk. Zdr. 2017;23(1):57-61 (in Polish).

13. Gacek M.: Zwyczaje żywieniowe grupy osób wyczynowo uprawiających siatkówkę. Rocz. Panstw. Zakł. Hig. 2011;62(1):77-82 (in Polish).

14. Hyży A.K., Krejpcio Z., Dyba S.: Ocena sposobu żywienia żołnierzy w wybranych jednostkach wojskowych [Evaluation of the method of soldiers' feeding in selected army units]. Probl Hig Epidemiol 2011;92(3):526-529 (in Polish).

15. Jarosz M. (red.) 2017: Normy żywienia dla populacji polskiej - nowelizacja. [Nutritional norms for the Polish population - revision.] Wyd. IŻŻ, Warszawa.

16. Kalinowski P., Mianowana M.: Zespół Metaboliczny cz. II: Epidemiologia zespołu metabolicznego w Polsce i na świecie. [Metabolic Syndrome part II: Epidemiology of metabolic syndrome in Poland and in the World]. J. Educ. Health Sport 2016;6(4):466-480 (in Polish) doi: 10.5281/zenodo.50681.

17. Kelly T., Wilson W., Heymsfield B.: Dual Energy X-Ray Absorptiometry Body Composition Reference Values from NHANES. PLoS ONE 2009;15:4(9):1-8.

18. Kłos A, Bertrandt J, Szymańska W., Walecka I.: Ocena stanu odżywienia studentów rozpoczynających naukę w Szkole Głównej Służby Pożarniczej w Warszawie. [Evaluation of the nutritional status of students entering the Main School of Fire Service in Warsaw]. Lek Wojsk 2010;88:250-254 (in Polish).

19. Kłos A., Bertrandt B., Bertrandt J., Łakomy R., Jemielniak M.: Ocena stanu odżywienia białkowoenergetycznego wybranego wojskowego personelu lotniczego. [Assessment of protein-energy nutritional status of selected military aviation personel]. Probl. Hig. Epidemiol. 2015;96(4):792-794 (in Polish).

20. Kłos A., Bertrandt J., Kurkiewicz Z.: Antropometryczna ocena stanu odżywienia załogi wybranej jednostki pływającej Marynarki Wojennej. [The assessment of nutritional status of the selected navy warship crew]. Rocz Panstw Zakl Hig 2007;58(1):259-265 (in Polish).

21. Kozłowska-Wojciechowska M.: Kardiodiabetologia. Zespół metaboliczny. Dieta a zespół metaboliczny. Jaki tłuszcz i w jakiej ilości jest niezbędny w diecie pacjentów z zespołem metabolicznym? [Diet and metabolic syndrome. What fat and in what amount is necessary in the diet of patients suffering from metabolic syndrome?]. Kardiologia Oparta na Faktach 2010;1(1):29-32 (in Polish).

22. Kreider R.B., Wilborn C.D., Taylor W.L., Campbell B., Almada A.L., Collins R., Cooke M., Earnest C.P., Greenwood M., Kalman D.S., Kerksick C.M., Kleiner S.M., Leutholtz B., Lopez H., Lowery L.M., Mendel R., Smith A., Spano M., Wildman R., Willoughby D.S., 
Ziegenfuss T.N.: ISSN Exercise and Sports Nutrition Review: Research and Recommendations. J. Int. Soc. Sports Nutr. 2010;7:1-7:7:43 doi: 10.1186/1550-27837-7.

23. Mettler S., Mannhart C., Colombani P.C.: Development and validation of a food pyramid for Swiss athletes. Int J Sport Nutr Exerc Metab 2009;19(5):504-18.

24. Peterlik, M., Kállay E., Cross E.: Calcium nutrition and extracellular calcium sensing: relevance for the pathogenesis of osteoporosis, cancer and cardiovascular diseases. Nutrients 2013;5(1):302-327 doi: 10.3390/ nu5010302.

25. Pietraszewska J., Burdukiewicz A., Andrzejewska J., Stachoń A.: Poziom i dystrybucja otłuszczenia oraz postawa ciała zawodowych żołnierzy i policjantów. [Body fat level and distribution and body posture of professional soldiers and policemen]. Probl Hig Epidemiol 2012;93(4):759-765 (in Polish).

26. Powers S., Nelson B. W., Larson-Meyer E.: Antioxidant and vitamin D supplements for athletes: Sense or nonsense? J. Sports Sci. 2011;29(1);47-55.

27. Reyes-Guzman C.M., Bray R.M., Forman-Hoffman V.L., Williams J.: Overweight and Obesity Trends Among Active Duty Military Personnel. A 13-Year Perspective. Am. J. Prev. Med. 2015;48(2):145-153 doi: 10.1016/j. amepre.2014.08.033.

28. Rozporządzenie Ministra Spraw Wewnętrznych i Administracji z dnia 11 października 2018 r. w sprawie wykazu chorób i ułomności, wraz z kategoriami zdolności do służby w Policji, Straży Granicznej, Straży Marszałkowskiej, Państwowej Straży Pożarnej oraz Służbie Ochrony Państwa. Dz.U. 2018 poz. 2035 [Journal of Laws 2018, item 2035].

29. Smith T.J., Marriott B.P., Dotson L., Bathalan G.P., Funderburk L., White A., Hadden L., Young A.J.: Overweight and obesity in military personnel: Sociodemographic predictors. Obes. Res. J. 2012;20:1534-1538 doi: 10.1038/oby.2012.25.
30. Szczepańska E., Spałkowska A.: Zachowania żywieniowe sportowców wyczynowo uprawiających siatkówkę i koszykówkę. [Dietary behaviours of volleyball and basketball players]. Rocz Panstw Zakl Hig 2012;63(4):483-489 (in Polish).

31. Szymańska W., Kłos A., Bertrandt J.: Ocena stanu odżywienia oraz częstotliwości spożywania posiłków wybranej grupy funkcjonariuszy policji. [Evaluation of nutritional status and meal consumption frequency among a selected group of police officers]. Probl. Hig. Epidemiol. 2014;95(3):778-782.

32. Teshima K., Imamura H., Yoshimura Y., Nishimura S., Miyamoto N., Yamauchi Y., Hori H., Moriwaki C., Shirota T.: Nutrient intake of highly competitive male and female collegiate karate players. J. Physiol. Anthropol. Appl. Human Sci., 2002;21:205-211.

33. Ubeda N., Palacios Gil-Antuñano, N., Montalvo Zenarruzabeitia Z., García Juan B., García, A., IglesiasGutiérrez E.: Food habits and body composition of Spanish elite athletes in combat sports. Nutr. Hosp. 2010;25(3):414-21.

34. Ustawa z dnia 12 października 1990 r. o Straży Granicznej. Dz.U. 1990 nr 78 poz. 462 [Act on the Border Guard of 12 October 1990, Journal of Laws 1990, No. 78, item 462].

35. Wojtyniak B., Goryński P. (ed.): Sytuacja zdrowotna ludności Polski i jej uwarunkowania. [Health status of Polish population and its determinants]. Narodowy Instytut Zdrowia Publicznego - Państwowy Zakład Higieny, Warszawa 2018, p. 87-88.

36. Zitvogel L., Pietrocola F., Kroemer G.: Nutrition, inflammation and cancer. Nat Immunol 2017;18(8):843-850.

Received: 03.04.2019

Accepted: 14.05.2019 